Article

\title{
Sustainability of the Moderating Role of Financial Development in the Determinants of Environmental Degradation: Evidence from Turkey
}

\author{
Husam Rjoub $^{1, *(\mathbb{C})}$, Jamiu Adetola Odugbesan ${ }^{2}\left(\mathbb{D}\right.$, Tomiwa Sunday Adebayo ${ }^{2}\left(\mathbb{D}\right.$ and Wing-Keung Wong ${ }^{3,4,5}$ \\ 1 Department of Accounting and Finance, Faculty of Economics and Administrative Sciences, \\ Cyprus International University, Nicosia 99040, Turkey \\ 2 Department of Business Administration, Faculty of Economics and Administrative Science, \\ Cyprus International University, Nicosia 99040, Turkey; odugbesanadetola@gmail.com (J.A.O.); \\ twaikline@gmail.com (T.S.A.) \\ 3 Department of Finance, College of Management, Asia University, Taichung City 41354, Taiwan; \\ wong@asia.edu.tw \\ 4 Department of Medical Research, China Medical University, Taichung City 40447, Taiwan \\ 5 Department of Economics and Finance, The Hang Seng University of Hong Kong, Hang Shin Link, \\ Siu Lek Yuen 41354, Hong Kong \\ * Correspondence: hrjoub@ciu.edu.tr
}

Citation: Rjoub, H.; Odugbesan, J.A.; Adebayo, T.S.; Wong, W.-K.

Sustainability of the Moderating Role of Financial Development in the Determinants of Environmental Degradation: Evidence from Turkey. Sustainability 2021, 13, 1844. https: / doi.org/10.3390/su1304 1844

Academic Editor: Flavio Boccia Received: 19 November 2020 Accepted: 3 February 2021

Published: 8 February 2021

Publisher's Note: MDPI stays neutral with regard to jurisdictional claims in published maps and institutional affiliations.

Copyright: (c) 2021 by the authors. Licensee MDPI, Basel, Switzerland. This article is an open access article distributed under the terms and conditions of the Creative Commons Attribution (CC BY) license (https:/ / creativecommons.org/licenses/by/ $4.0 /)$.

\begin{abstract}
One of the questions that remain unanswered in the literature on determinants of carbon emissions is the moderating effect of "financial development". This becomes imperative, owing to the connection of carbon emissions to environmental degradation, which is considered to be one of the main challenges to sustainable development. Thus, this study investigated the moderating role of financial development in the determinants of carbon emissions for Turkey during the period of 1960 to 2016. Zivot-Andrew and Lee-Strazicich "unit root tests" were utilized to investigate the stationarity properties of the series. The cointegration among the variables employed was examined by utilizing the ARDL bounds test and Bayer-Hanck cointegration test. In contrast, the long-run causal relationship of the variables with carbon emissions was examined by using fully modified ordinary least square (FMOLS), dynamic OLS (DOLS), and Canonical Cointegrating Regression (CCR). The empirical findings reveal the significance of "economic growth", "capital formation", "energy consumption", "urbanization", and "financial development" as determinants of environmental degradation in Turkey. The study also found the significant moderating role of "financial development" in the relationship between "economic growth" and carbon emissions, capital formation and carbon emissions, and urbanization and carbon emissions. The environmentalfinancial related policies were suggested for the policymakers in Turkey to aid the reduction of carbon emission with the view of improving environmental quality.
\end{abstract}

Keywords: global warming; $\mathrm{CO}_{2}$ emissions; environmental degradation; sustainability; Turkey

JEL Classification: C01; Q01; Q28; Q53; Q56

\section{Introduction}

In reference to the "Intergovernmental Panel on Climate Change", air pollution and global warming were considered to be the most significant issues in the last few decades [1], and the cited carbon dioxide $\left(\mathrm{CO}_{2}\right)$ emissions were found to be the determinant of these challenges, and also a challenge to sustainability [2]. For instance, Turkey was ranked 51st of 61 countries globally in terms of climate-change protection, according to the climatechange performance index in 2015, and the country was criticized for its absence of national policies to prevent climate change [3]. The "International Energy Agency" (IEA) posits that "energy-related $\mathrm{CO}_{2}$ emissions" in Turkey began to increase rapidly during the 1990s, and 
between 1990 and 2012, there was an increase of $138.3 \%$ change in $\mathrm{CO}_{2}$ emissions in the country [4]. According to the World Bank [5], Turkey is a non-industrial nation with US $\$ 754.412$ billion "gross domestic product (GDP)" and "per capita GDP" of US \$14,998.98 in 2019. The percentages of exports and imports of goods and services were $31.61 \%$ and $29.78 \%$, individually, for 2019. Bilgen et al. [6] saw that Turkey is described by fast financial development, as well as its expanding pace of urbanization, unbending energy utilization, and expanding $\mathrm{CO}_{2}$ emissions with hefty dependence on imported energy assets, which Kalmaz and Kirikkaleli [7] noticed are liable for the principle wellspring of present record deficiencies for quite a long while. It was estimated by World Bank [5] that 75\% out of the total energy consumption in Turkey was imported from overseas in 2015. This indicates the level of Turley reliance on foreign energy resources, whereas, according to Türkiye İstatistik Kurumu (TÜIK) [8], GHG is mostly generated by energy consumption, with over $80 \%$ of $\mathrm{CO}_{2}$ emissions out of the total GHG in Turkey. In the case of Turkey, for instance, Akca, Ozturk, and Gunes [9] considered air pollution to be among the causes of lung cancer and respiratory disease. In contrast, a nation is said to be sustainable "when it does not deplete or disrupt ecosystems to the prejudice of the livelihoods and well-being of others now or in the future" [10]. Akca et al. [9], in addition, stated that the challenges of environmental pollution in Turkey are not limited to urban areas and the rural areas, which indicates that the achievement of "sustainable development" in the country is under threat.

The significance of $\mathrm{CO}_{2}$ emissions as a great contributor to "greenhouse gas (GHG) emissions" was emphasized by the Intergovernmental Panel on Climate Change (IPCC), which reported that about $76.6 \%$ of "GHG emissions", which consist of $\mathrm{CO}_{2}$ emissions, emanate from emerging economies countries with the view of ensuring acceleration of their "growth rate" and "national production" to achieve better economic conditions [3,11,12]. According to Kirikkaleli and Kalmaz [7], improved economic growth enhances living standards, but it also leads to urbanization increase and energy consumption, which are contributors to high levels of $\mathrm{CO}_{2}$ emissions, which could be the result of "overuse" or "misallocation" of energy resources that is often predominant in less-developed countries [13]. Three strands were notably identified in the studies that concentrate on this debate. Firstly, the validity of Environmental Kuznets Curve (EKC) theory was investigated by examining the economic growth effect on carbon emissions [14-16]. In reference to Lorente and Alvarez-Herranz [17], it was in the EKC theory that the nexus between $\mathrm{CO}_{2}$ and economic growth displayed an inverted U-shape, which indicates that, at the initial stage of economic growth, pollution increases but starts declining when it arrives a threshold as a result of improved technology, regulations on the environment both at "intergovernmental" and "global level", and educating the public about the increase, which contributes to the amelioration of environmental degradation. The second strand in the literature on EKC investigates the effect of economic growth on energy consumption, using causality and cointegration tests, in line with the study of Kraft and Kraft [18], which is in line with another study that revealed "energy consumption" to be among the "environmental degradation" determinant factors [19]. In the third strand, the two dimensions in the literature on EKC were combined with the inclusion of "energy consumption" and other economic variables for further analysis "EKC hypothesis", to address the omission of "variable bias" in the literature [20-26]. Meanwhile, there has not been a consensus on the "EKC hypothesis", owing to the different outcomes from different studies from a different region. Therefore, it becomes imperative to consider "country-specific" indicators for investigation.

Despite how a couple of assessments have attempted to investigate the impact of different economic-related indicators on EKC [7,27-31], to the best of our understanding, the possible moderating effect of financial development has not been investigated. This formed the main focuses, similarly to the uniqueness, of the current assessment. The study of Aye and Edoja [32] highlighted four theoretical perspectives due to related economic progression on $\mathrm{CO}_{2}$ emissions, including the "eco-friendly technology", the Foreign Direct Investment (FDI), improvement in the manufacturing industry, and the perspective con- 
sumers' credit improvement. The suggestion that "financial development" decreases $\mathrm{CO}_{2}$ when the money-related business areas makes a course of action for financial assistance to the close by firms so they can get eco-friendly and clean technology for industrial purposes. This speculative perspective was affirmed by the examination of Yuxiang and Chen [33], who said that the financial market in China gives financing and concentrated assistance that engages the associations to grasp new and improved technology that improves their production and at the same time reduce the $\mathrm{CO}_{2}$ radiations. The examination of Frankel and Rose [34], in like manner, accepted that the financial market could effectively allocate money-related resources for domestic firms to enable them to purchase pleasant atmosphere technology. A couple of examinations saw that there would be an increase in $\mathrm{CO}_{2}$, on the one hand, if financial progression leads to demands for energy-using advancements [35-37]. In contrast, "credit facilities" and "investment channels", given by the related money system and overall trade, may give space for an engaging atmosphere for inventive work of low-carbon energy sources if money-related improvement is intertwined into eco-friendly policies and rules [38,39]. This implies that financial improvement could reduce environmental defilement by decreasing carbon emissions in the economy [40].

At that point, near assessments have a lot of the composing that focused in on a couple of pointers of $\mathrm{CO}_{2}$ releases in Turkey [3,7,41,42]; regardless, the fundamental question of how financial progression impacts characteristic degradation in Turkey really requires further assessment. Our examination hopes to address this huge request by considering the coordinating position of "financial development" for various determinants of environmental degradation, since financial development makes a correspondence through influencing environmental degradation, just as addition economic growth, advance gross fixed capital plan, raise energy usage, and augmentation urbanization, as proposed in the literature $[3,7,35-40,43]$. Notwithstanding the way that most of these examinations used a proper model for the assessment, at this point, they fail to consider the moderating position of financial development. This assessment aims to fill the opening inside Turkey's setting, since Turkey is an intriguing examination setting both in the methodology field and the educational, as being the third most raised $\mathrm{CO}_{2}$ emissions creating a country with the least energy use among the EU part countries [7]. These real factors show the imperativeness of reshaping the public environmental policies in Turkey to control the $\mathrm{CO}_{2}$ releases and reduce the defilement to a particular commendable level for the improvement of environmental quality. Thus, unprecedented for the composition, the impact of gross capital formation (GCF), GDP, energy use, urbanization, and financial development on $\mathrm{CO}_{2}$ emissions inside the setting of Turkey is fused by this assessment, through using novel econometric strategies and considering the moderation effect of financial development to address the opening in the literature and to have the choice to give strong observational disclosures to policymakers. The contribution of this paper lies in the application of novel econometric techniques, the inclusion of new variables to the EKC hypothesis, and the conducting of the study within the setting of Turkey, which has not been exhaustively investigated. The findings will be valuable to the policymakers in formulating an environmental and financial-related policy that will ensure the improvement of the financial market and reduce carbon emission, with the view of ensuring a clean environment. Thus, the purpose of the paper is to examine the significance of different economic factors on environmental degradation and the possible moderating effect of financial development, which, to the best of the authors' knowledge, has not been investigated especially in the context of Turkey. This was the main purpose of this study, as well as the novelty of our research. The significance of financial development on environmental degradation should not be underestimated, owing to its possible relationship with energy consumption and economic growth, which have been identified as being among the factors that trigger environmental degradation.

The remainder of the paper is composed as follows. A review of experimental assessments from the literature is discussed in Section 2. Data description, sources, and strategy 
are given in Section 3. The specific disclosures are presented in Section 4, and Section 5 contains the discussion and conclusion.

\section{Review of Related Studies}

In recent times, the issue of environmental pollution is becoming promising, and the attention received in the discussion among various stakeholders has increased, since environmental pollution is believed to be the genesis cause of both climate change and global warming $[13,43]$. Climate change and global warming are believed to impose a catastrophic adverse impact on people's livelihoods and on the pace of economic growth, especially in industrialized countries. Meanwhile, Kirikkaleli and Kalmaz [7] observed that developing countries aim to improve their "economic growth" for a good standard of living, which would be achieved by enhancing the production output. The increased output in these countries results in to increase in energy consumption and level of urbanization, which in turn contributes to the high levels of $\mathrm{CO}_{2}$ emissions via the misapplication or misallocation of energy resources [7]. Several studies abound in the literature that concentrate on this debate. Several of these studies have employed econometrics methods and procedures to empirically examine the nexus between economic growth, energy consumption, and carbon emissions. Some of these studies are country-specific (time series analysis) or panel studies, and three strands could be identified in the literature.

The first strand in the literature was under the "Environmental Kuznets Curve" $(\mathrm{EKC})$, which posits that $\mathrm{CO}_{2}$ increases, until it gets to a threshold level of income, which is reached when there is an increase in income. After that level, as there increase in income, the $\mathrm{CO}_{2}$ emissions start decreasing. Several studies have investigated the EKC hypothesis $[14,16,44-46]$. The second school of thought belongs to those that follow Kraft and Kraft [18], who investigated the nexus between "energy consumption" and "carbon emissions". Some of these studies utilized causality and cointegration tests [19,20,41,47-52]. The third strand is those studies that combine the first two dimensions and introduced energy consumption into the nexus between income and carbon emission to address the challenges of "omitted variable bias" of the EKC hypotheses [7,21-24,53,54]. About Turkey, several studies have investigated the EKC hypothesis extensively. The study of Haliciolglu [54] employed Autoregressive Distributed Lag (ARDL) testing techniques for determining the nexus between energy consumption and carbon emissions in the long run. The study found the existence of EKC in Turkey. A similar study was conducted by Ozturk and Acaravci [55], to investigate the EKC in Turkey, using data from 1968 to 2005. Different from the finding of Halicioglu [54], Ozturk and Acaravci [55] demonstrated that EKC is not valid for the period examined. However, in their study in 2013, the EKC was confirmed when financial development and trade were included with energy consumption, economic development, and $\mathrm{CO}_{2}$ [56]. Similarly, the EKC hypothesis was confirmed in the case of study in the study of Shahbaz et al. [39], which investigated the relationship between $\mathrm{CO}_{2}$, economic growth, energy intensity, and globalization, using data that spanned between 1970 and 2010. The study employed a "unit root test" and "cointegration technique" under the existence of structural breaks. A recent study by Kirikkaleli and Kalmaz [7] confirmed the validity of the EKC hypothesis for Turkey and also demonstrated that energy consumption, trade, and urbanization are significant determinants of $\mathrm{CO}_{2}$ emissions in Turkey. This finding corroborates the findings of Kalmaz and Kirikkaleli [7], who demonstrated that $\mathrm{CO}_{2}$ emission is triggered by energy consumption, economic growth, and urbanization.

As a result of the inconclusive findings on the relationship between energy use, economic development, and carbon emissions, some studies have attempted to include some indicators in their studies, among which is "gross fixed capital formation" (GFCF) [51,57-59]. These studies see GCF as a proxy for capital on the ground that changes in capital stock impact changes in investment, which is predicated on the standard assumption of a constant depreciation rate using the perpetual inventory techniques [60-62]. The study of Solarin and Shabaz [63] investigated the nexus between natural gas consumption and economic 
growth, including FDI, capital formation, and trade openness in Malaysia, using data that covers the period from 1971 to 2012. The study employed a structural break unit root test and cointegration techniques. ARDL was employed for the study robustness, and the study established a cointegration among the variables and also demonstrated the significant effect of FDI, natural gas consumption, capital formation, and trade openness on the economic growth in Malaysia. Several studies have also examined the effect of capital formation in a different context and found its significant relationship with economic growth [57,64-67] and the consequent impact on environmental pollution through carbon emissions.

Economic growth in some countries, especially developing countries, increases the rate of urbanization [68]. Urbanization has been found, in some studies, to have a significant relationship with energy consumption and environmental pollution $[69,70]$. These studies posit that about $75 \%$ of the energy consumption and $60 \%$ of carbon emission globally have been accounted for by urban spaces. Moreover, a few examinations contended that urbanization is a critical determinant of carbon emissions [7,71-73]. The writing in such a manner uncovers the presence of three hypotheses that inspect the nexus among urbanization and the natural environment. The hypotheses are natural modernization [74], metropolitan ecological change [75], and "compact city theories" [76]. These hypotheses imply that the impact of urbanization on the climate can be positive or negative contingent upon the net effect, and, what is more, that financial exercises sway the metropolitan and mechanical spaces; in this manner, urbanization impacts fossil fuel byproducts [77-84].

From the observational perspective, studies flourish on the connection between financial development and $\mathrm{CO}_{2}$ discharges. For example, Shahbaz et al. [38] examined the nexus among economic development, trade openness, energy utilization, financial development, and $\mathrm{CO}_{2}$ emissions in Indonesia, utilizing ARDL, Vector Error Correction Model (VECM), and the novel accounting way to deal with Granger causality. The discoveries from the examination demonstrate that, while in the oil-plentiful economy, energy utilization, and monetary development drive $\mathrm{CO}_{2}$ emissions, the development of financial markets and trade openness adds to the decrease of $\mathrm{CO}_{2}$ emanations. The investigation of Sy et al. [85] researched the interrelationship between development in the financial market, $\mathrm{CO}_{2}$ outflows, and economic development in 40 European nations, utilizing OLS procedures. The investigation found, among others, the presence of impartiality theory between financial development and $\mathrm{CO}_{2}$ emanations. Furthermore, the connection between financial development and $\mathrm{CO}_{2}$ emissions was inspected by Charfeddine and Khediri [86], dependent on the EKC theory for United Arab Emirates (UAE). The examination uncovered a modified U-formed connection between financial development and environmental degradation, which shows that environmental degradation increases as the monetary area develops and then reduce when the monetary areas get to the maturity level and produce effectiveness in the designation of assets. A comparable report was led in Bangladesh by Alom et al. [87], and the examination found a positive effect of monetary advancement on $\mathrm{CO}_{2}$ discharges. Kong and Wei [88] examined the nexus between financial development and $\mathrm{CO}_{2}$ outflow, utilizing panel data that included China's 30 areas. The investigation hypothesized that low monetary improvement adds to the decrease of $\mathrm{CO}_{2}$, while more elevated levels of monetary advancement bring about an expansion in $\mathrm{CO}_{2}$ emanations. The impact of monetary improvement on carbon emissions in 129 nations was investigated by Al-Mulali et al. [89]. The outcome uncovered that monetary advancement in the shortand long-run improves the quality of the environment inferable from its negative effect on $\mathrm{CO}_{2}$ emissions. The investigation of Nasreen et al. [90] was inclined towards the assurance of the impact of monetary dependability on the $\mathrm{CO}_{2}$ outflows. The outcome affirmed the commitment of monetary strength to the decrease of ecological corruption. A new report by $\mathrm{Xu}$ et al. [36] inspected the nexus between financial development and environmental degradation in Saudi Arabia by utilizing the ARDL and VECM. The examination uncovered a huge and positive relationship and bidirectional causality between financial development and environmental degradation. 
Evidence from the literature indicates that the existing studies have not exhaustively investigated the determinants of carbon emissions, hence the need for further studies. Thus, this study aimed to highlight the possible moderating effect of financial development on Turkey's "environmental quality", using the "Zivot-Andrew unit root test", "LeeStrazicich unit root test", Bayer and Hack [91] "cointegration test", and "fully modified ordinary least square (FMOLS)" in reference to the suggestion of Shabaz et al. [43] that it would be helpful for policymakers to articulate a sound environmental-related policy for "sustainable development" of the individual country if the researcher can employ new econometrics approach for different panels and time-series data.

Moreover, in reference to the extant literature reviewed, this study hypothesized, in Equation (1), the significance of variables (economic growth, energy consumption, gross capital formation, urbanization, and financial development) employed in this study individually on environmental degradation. In addition, it was hypothesized in Equation (2) that financial development will moderate the possible relationship of energy consumption, economic growth, gross capita formation, and urbanization with environmental degradation.

\section{Data, Method Specification, and Techniques Utilized}

\subsection{Data}

We studied the impact of urbanization (URB), economic growth (Y), gross capital formation (GCF), financial development (FD), and energy consumption (EN) on carbon emissions $\left(\mathrm{CO}_{2}\right)$ because this is one of the most important environmental issues that has been drawing increasing interest over the past years. In addition, we examined the moderating effects of the financial development on the effects of URB, GDP, GCF, and EN on $\mathrm{CO}_{2}$ emissions in Turkey. Table 1 depicts the description, units, and sources of the data that were studied for this paper.

Table 1. Variables units and sources.

\begin{tabular}{|c|c|c|c|}
\hline Variable & Description & Units & Sources \\
\hline $\mathrm{CO}_{2}$ & $\begin{array}{l}\text { Environmental } \\
\text { Degradation }\end{array}$ & $\mathrm{CO}_{2}$ emissions metric tons & \multirow{6}{*}{$\begin{array}{l}\text { Word Development } \\
\text { Indicators (WDI, } \\
\text { 2020) }\end{array}$} \\
\hline $\mathrm{Y}$ & Economic Growth & $\begin{array}{c}\text { GDP per capita } \\
\text { constant } \$ \text { US, } 2010\end{array}$ & \\
\hline URB & Urbanization & Urban population & \\
\hline $\mathrm{EN}$ & Energy Consumption & $\begin{array}{l}\text { kg of oil equivalent per } \\
\text { capita }\end{array}$ & \\
\hline FD & Financial Development & $\begin{array}{l}\text { Domestic credit to private } \\
\text { sector by banks ( } \% \text { of GDP) }\end{array}$ & \\
\hline GCF & Gross Capital Formation & $\begin{array}{l}\text { Gross capital formation } \\
\text { (current US \$) }\end{array}$ & \\
\hline
\end{tabular}

\subsection{Model Specification}

The study examined the impacts of GDP growth, gross capital formation, urbanization, financial development, and energy consumption on $\mathrm{CO}_{2}$ emissions in Turkey. Furthermore, we examined the moderating role of financial development in regards to the impacts of urbanization, gross capital formation, economic growth, and energy consumption on $\mathrm{CO}_{2}$ emissions in Turkey. To do so, we used the natural logarithms of all the data being used and based on the two broad objectives, to formulate the following two models:

$$
\begin{gathered}
C O_{2}=f(Y, E N, G C F, F D, U R B), \\
C O_{2}=f(F D(Y), F D(E N), F D(G C F), F D(U R B)),
\end{gathered}
$$


where $\mathrm{CO}_{2}$ represents the carbon emissions, GCF depicts the gross capital formation, EN illustrates energy consumption, Y stands for GDP per capita, and URB and FD represent urbanization and financial development, respectively. We then used the following two econometric models to estimate Equations (1) and (2), respectively:

$$
\begin{gathered}
C O_{2}=\vartheta_{0}+\vartheta_{1} Y_{t}+\vartheta_{2} E N_{t}+\vartheta_{3} G C F_{t}+\vartheta_{4} F D_{t}+\vartheta_{5} U R B_{t}+\varepsilon_{t} \\
C O_{2}=\vartheta_{0}+\vartheta_{1} F D(Y)_{t}+\vartheta_{2} F D(E N)_{t}+\vartheta_{3} F D(G C F)_{t}+\vartheta_{5} F D(U R B)_{t}+\varepsilon_{t},
\end{gathered}
$$

where $\vartheta_{0}$ depicts the constant term, $\vartheta_{1} \ldots \ldots \vartheta_{5}$ are the long-run elasticities of the regressors, and $t$ and $\varepsilon$ illustrate the time and error term, respectively. Figure 1 illustrates the study research model.

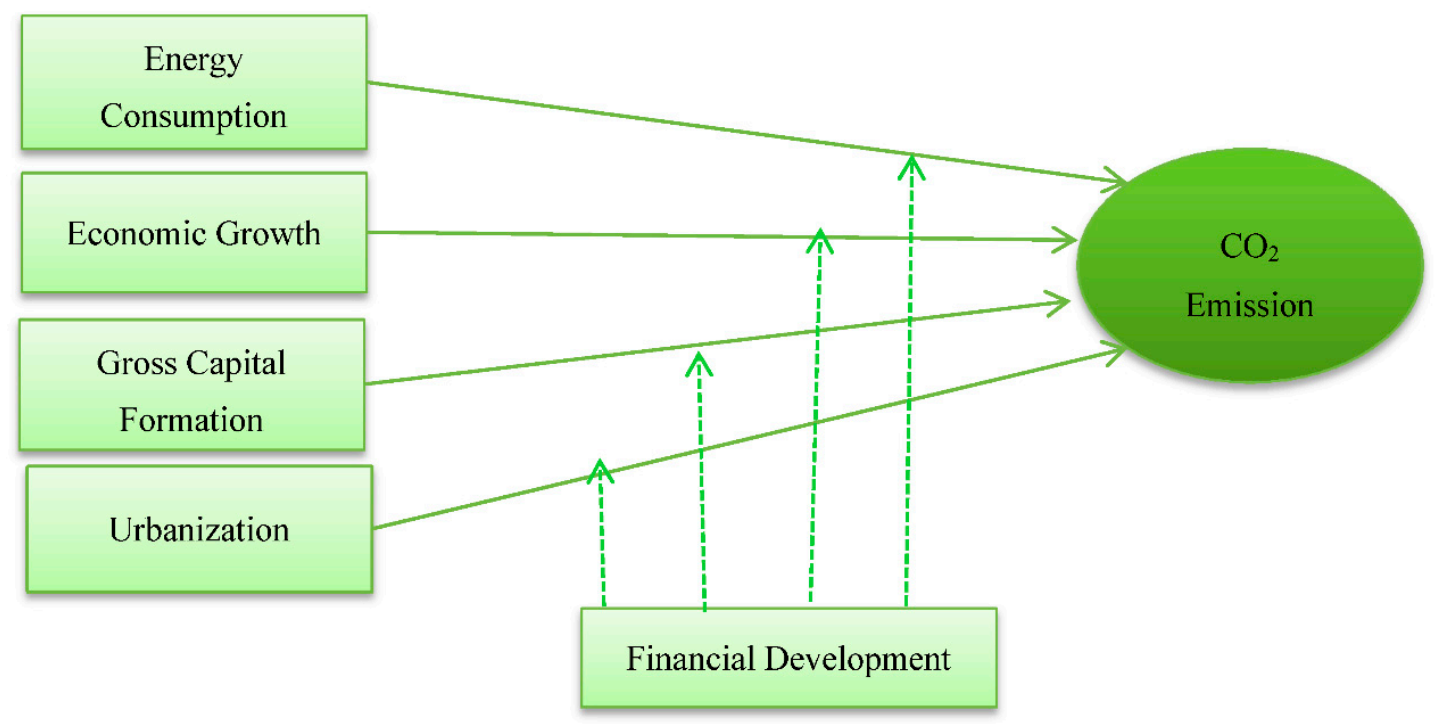

Figure 1. Research model.

\subsection{Techniques Employed}

\subsubsection{Unit Root Tests}

Although several traditional unit-root tests can be used to capture the stationarity characteristics of the variables, we did not employ them in our study, because Kalmaz and Kirikkaleli [7] asserted that the traditional unit-root tests yield ambiguity and erroneous outcomes if there is evidence of breaks in the series. To circumvent the limitations of the traditional unit-root tests, we utilized the Zivot-Andrew and Lee-Strazicich unit root tests that can identify breaks and capture the stationary features in the presence breaks for the series.

\section{Zivot-Andrew Unit-Root Test}

The Zivot-Andrew (Zivot and Andrews (ZA) [92]) depicted as follows:

$$
\begin{gathered}
\text { Model 1: } \Delta x_{t}=\varphi+\varphi x_{t-1}+\pi t+\delta D U_{t}+\sum_{j=1}^{k} d_{j} \Delta x_{t-j}+\mu_{t}, \\
\text { Model 2: } \Delta x_{t}=\varphi+\varphi x_{t-1}+\pi t+\gamma D T_{t}+\sum_{j=1}^{k} d_{j} \Delta x_{t-j}+\mu_{t}, \\
\text { Model 3: } \Delta x_{t}=\beta+\beta x_{t-1}+\beta t+\theta D U_{t}+\theta D T_{t}+\sum_{j=1}^{k} d_{j} \Delta x_{t-j}+\mu_{t},
\end{gathered}
$$


can reveal unit root characteristics for any series in the present of one structural break, where $D U_{t}$ depicts dummy parameter for mean shift arising at each probable break (TB), and $D T_{t}$ is the trend shift variable:

$$
D U_{t}=\left\{\begin{array}{c}
1 \ldots \text { if } t>T B \\
0 \ldots \text { if } t<T B
\end{array} \text { and } D T_{t}=\left\{\begin{array}{c}
t-T B \ldots \text { if } t>T B \\
0 \ldots . \text { if } t<T B
\end{array} .\right.\right.
$$

There are three options when implementing the ZA unit root test, including at intercept, trend, and both intercept and trend. Model 1 (Equation (2)) depicts Zivot-Andrews at the intercept, Model 2 (Equation (3)) depicts Zivot-Andrews at Trend, and Model 3 (Equation (4)) depicts Zivot-Andrews at both intercept and trend. We adopt Model 3 in our analysis because it combines the characteristics of both intercept and trend together. In the three models, the null hypothesis demonstrates that the series $x_{t}$ encompasses a unit-root with a drift that disregards any break, whereas the alternative hypothesis illustrates that the parameter follows a stationary trend procedure with a single break that appears at an unidentified time.

\section{Lee-Strazicich Unit-Root Test}

Lee and Strazicich [93] developed the Lagrange Multiplier (LM) based structural break test to circumvent the incorrect rejection problem arisen from the Zivot-Andrews [92] and Phillips-Perron [94] unit-root tests. Consider the following data-generation phase (DGP):

$$
y_{t}=\delta^{l} Z_{t}+e_{t}, e_{t}=\beta e_{t-1}+e_{t}
$$

where a vector of exogenous variables is depicted by $Z_{t}$ and $\varepsilon_{t} \backsim \operatorname{IIDN} N\left(0, \sigma^{2}\right)$. The Lee-Strazicich unit root test permitting the presence of an internally determined structural fracture is an LM unit root test centered on two models: the fracture (Model A) and trend (Model B). The two structural breaks can be interpreted as follows: Model A defined as $Z_{t}=\left[1, t, D_{1 t}, D_{2 t}\right]$ enables two shifts in the level in which $D_{j t}=1$ for $t \geq T_{B j}+$ $1, j=1,2$, and 0 otherwise represents the timeframe when a break happens. Model $\mathrm{B}$ defined by $Z_{t}=\left[1, t, D_{1 t}, D T_{2 t}, D T_{2 t},\right]^{\iota}$ describes two changes both level and trend where $D T_{j t}=t-T_{B j}$ for $t \geq T_{B j}+1, j=1,2$, and 0 otherwise. Recall that DGP contains breaks underneath the null $(\beta=1)$ versus the alternative $(\beta<1)$ hypotheses. In Model $A$, the following equations are used in testing the hypotheses:

$$
\begin{aligned}
& y_{t}=\mu_{o}+\delta_{1} \beta_{1 t}+\delta_{2} \beta_{2 t}+y_{t-1}+v_{i t}, \\
& y_{t}=\mu_{o}+\gamma_{t}+\delta_{1} D_{1 t}+\delta_{2} D_{2 t}+v_{2 t},
\end{aligned}
$$

where error terms are denoted by $v_{i t}$ and $v_{2 t}$, respectively, $d=\left(\delta_{1}, \delta_{1}\right)$, y is the trend parameter, and $\beta_{j t}=1$ for $t=T_{B j}+1,2$ and 0 otherwise. The two-break Lee-Strazicich unit-root test is then implemented by utilizing the following regression:

$$
\Delta y_{t}=\delta^{l} \Delta Z_{t}+\varnothing \widetilde{S}_{t-j}+\sum_{i-1}^{k} \lambda_{i} \Delta \widetilde{S}_{t-j}+\varepsilon_{t}
$$

Similarly to the two-break counterpart of Phillips and Perron [94], in Model B, $Z_{t}$ is demarcated by $\left[1, t, D_{1 t}, D T_{2 t}, D T_{2 t},\right]^{\iota}$, to permit for a constant term, linear time-trend, and two breaks in both level and trend. The null hypothesis is tested by using $\varnothing=0$, and the LM T-statistics are portrayed by the following equation:

$$
\widetilde{P}=T \widetilde{\varnothing}
$$


in order to determine the endogenous break-point $T_{B j}$. The minimum LM unit root test utilizes a grid search by using the following two equations:

$$
\begin{aligned}
& L M_{p}=\inf \widetilde{p}(\widetilde{\lambda}), \\
& L M_{p}=\inf \widetilde{\tau}(\widetilde{\lambda}),
\end{aligned}
$$

where $T_{b} / T$, and $T$ is the sample size. In applying the LM test, the studentized version $\tilde{\tau}$ considered, the capriciousness of the coefficients estimated is more potent than the coefficient test $\widetilde{p}$ [95]. The break-points are observed when the T-statistic is minimized. As anticipated in the endogenous brake test, a trimming region of $(0.15 \mathrm{~T}, 0.85 \mathrm{~T})$ is utilized to eradicate end-points.

\subsubsection{ARDL Bounds Test}

We employed the ARDL bounds test developed by Pesaran et al. [96] bounds test to detect whether there was any long-term cointegration among the variables being studied in this paper, because it has several advantages over other traditional cointegration techniques $[63,97]$. Firstly, it can be used when variables are integrated with different mixed orders. Secondly, it is more robust for small samples. Thirdly, it can be used for long-term framework impartial evaluations. Furthermore, if the F-stat surpasses the lower and upper bound values, it confirms a long-run interconnection among the variables. The ARDL bounds test is specified in the following equations:

$$
\begin{aligned}
\Delta C O_{2 t}=\vartheta_{0} & +\sum_{i=1}^{t} \vartheta_{1} \Delta C O_{2 t-i}+\sum_{i=1}^{t} \vartheta_{2} \Delta G D P_{t-i}+\sum_{i=1}^{t} \vartheta_{3} E N_{t-i}+\sum_{i=1}^{t} \vartheta_{4} \Delta G C F_{t-i}+\sum_{i=1}^{t} \vartheta_{5} \Delta F D_{t-i} \\
& +\sum_{i=1}^{t} \vartheta_{6} \Delta U R B_{t-i}+\beta_{1} C O_{2 t-1}+\beta_{2} G D P_{t-1}+\beta_{3} E N_{t-1}+\beta_{4} G C F_{t-1}+\beta_{5} F D_{t-1} \\
& +\beta_{6} U R B_{t-1}, \\
\Delta C O_{2 t}=\vartheta_{0}+ & +\sum_{i=1}^{t} \vartheta_{1} \Delta C O_{2 t-i}+\sum_{i=1}^{t} \vartheta_{2} \Delta F D(G D P)_{t-i}+\sum_{i=1}^{t} \vartheta_{3} F D(E N)_{t-i}+\sum_{i=1}^{t} \vartheta_{4} \Delta F D(G C F)_{t-i} \\
& +\sum_{i=1}^{t} \vartheta_{5} \Delta F D(U R B)_{t-i}+\beta_{1} C O_{2 t-1}+\beta_{2} F D(G D P)_{t-1}+\beta_{3} F D(E N)_{t-1}+\beta_{4} F D(G C F)_{t-1}+ \\
& +\beta_{5} F D(\text { URB })_{t-1}+\varepsilon_{t},
\end{aligned}
$$

where $\vartheta_{\mathrm{i}}$ is the coefficient of the long-run multiplier, and $\beta_{i}$ is the coefficient of the short-run multiplier for $i=1,2,3,4$, and 5 .

\subsubsection{Bayer and Hanck Combined Cointegration}

As a robustness check, the study further utilized the Bayer and Hanck [91] cointegration test, which is a combination of Engle and Granger [98], Johansen [99], Boswijk [100], and Banerjee et al. [101] cointegration tests. According to the Bayer and Hanck [91] cointegration test yields effective estimation by removing unnecessary multiple test techniques created by other cointegration tests. Bayer and Hanck [91] utilize Fisher's formula in the construction of the cointegration test to strengthen the test. Fisher's equation is illustrated by Bekun et al. ([102], p. 761), as shown by the following equations:

$$
\begin{gathered}
E G-J O H=-2[\ln (P E G)+\ln (\mathrm{PJOH})], \\
\mathrm{EG}-\mathrm{JOH}-\mathrm{BO}-\mathrm{BDM}=-2[\ln (\mathrm{PEG})+\ln (\mathrm{PJOH})+\ln (\mathrm{PBO})+\ln (\mathrm{PBDM})],
\end{gathered}
$$

where the level of significance for the test developed by Engle and Granger [99] is indicated by PEG, and the level of significance of Johansen (1991) is represented by PJOH. The level of significance for Boswijk [98] and Banerjee et al. [101] cointegration tests is depicted by $\mathrm{PBO}$ and PBDM, respectively. 
Long-Run Elasticities (FMOLS, Dynamic Ordinary Least Square (DOLS), and Canonical Cointegrating Regression (CCR))

In this study, we first used a single cointegrating vector to analyze the long-term interconnection. We then employed several econometric methods to explore the longrun interaction among the variables, including fully modified OLS (FMOLS) developed by Phillips and Hansen [103] and Dynamic OLS and Canonical Cointegrating Regression (CCR) methods developed by Stock and Watson [104]. These techniques possess asymptotic coherence obtained by considering the impact of serial correlation and the endogeneity test from the existence of a cointegrating interaction. FMOLS, DOLS, and CCR can be implemented only if the existence of cointegration amongst the variables is confirmed. Thereafter, the long-term elasticity is estimated in this analysis by utilizing FMOLS, DOLS, and CCR estimators.

\section{Empirical Findings}

We first exhibit in Table 2 the descriptive statistics of all the variables studied in this paper. From the table, we confirm that all the variables are normally distributed, except for financial development, gross capital, and urbanization, as confirmed by using kurtosis and skewness values and the Jaqua-Bera test.

Table 2. Descriptive statistics.

\begin{tabular}{ccccccc}
\hline Variable & $\mathbf{C O}_{\mathbf{2}}$ & GDP & EN & FD & GCF & URB \\
\hline Mean & 2.543394 & 7094.831 & 945.3779 & 24.03407 & $6.70 \times 10^{10}$ & $30,620,236$ \\
Median & 2.585579 & 6389.743 & 922.8943 & 18.48454 & $2.40 \times 10^{10}$ & $30,068,892$ \\
Max & 5.130000 & 14874.78 & 1651.361 & 66.42597 & $2.83 \times 10^{11}$ & $60,537,696$ \\
Min & 0.612271 & 3134.777 & 385.4710 & 12.72601 & $8.00 \times 10^{8}$ & $8,657,910$ \\
SD & 1.216030 & 3081.219 & 376.0348 & 13.97705 & $8.93 \times 10^{10}$ & $15,940,485$ \\
Skewness & 0.195523 & 0.840432 & 0.273774 & 1.997102 & 1.342495 & 0.236220 \\
Kurtosis & 1.995324 & 2.837814 & 1.951382 & 5.759719 & 3.254217 & 1.753007 \\
JB & 2.808870 & 6.891379 & 3.381907 & 56.96015 & 17.57835 & 4.297292 \\
Prob & 0.245506 & 0.031883 & 0.184344 & 0.000000 & 0.000152 & 0.116642 \\
\hline
\end{tabular}

Note: SD, JB, Min, Prob, and Max are standard deviation, Jaqua-Bera, minimum, probability, and maximum, respectively.

We first employed the Zivot and Andrew (ZA) and the Lee and Strazicich (LS) unit root tests, to capture the order of integrations and structural breaks and exhibit the results in Tables 3 and 4, respectively. The outcomes of the ZA unit root test depicted in Table 3 reveal that all the series are not stationary at level. However, after the first difference is taken, all the series are stationary with a structural break in 2006, 2001, 1995, 2005, 2004, and 1990 for $\mathrm{CO}_{2}$, EN, GDP, GCF, FD, and URB, respectively. The outcomes of the LS unit root test portrayed in Table 4 show that all the series are stationary with different mixed levels, except for GCF, which becomes stationary after differencing.

Table 3. Zivot and Andrews (ZA) unit-root test.

\begin{tabular}{|c|c|c|c|c|c|c|}
\hline \multirow{2}{*}{ Variables } & & \multicolumn{2}{|c|}{ Level } & \multicolumn{2}{|c|}{ First Difference } & \multirow[b]{2}{*}{ Decision } \\
\hline & & T-Statistic & Break-Year & T-Statistic & Break-Date & \\
\hline $\mathrm{CO}_{2}$ & \multirow{6}{*}{$\mathrm{K}$ and $\mathrm{T}$} & -3.430 & 2004 & $-7.054^{\mathrm{B}}$ & 2006 & $\mathrm{I}(1)$ \\
\hline EN & & -3.180 & 1981 & $-6.866^{B}$ & 2001 & $\mathrm{I}(1)$ \\
\hline GDP & & -4.235 & 2011 & $-7.007^{\mathrm{B}}$ & 1995 & $\mathrm{I}(1)$ \\
\hline GCF & & -3.382 & 2010 & $-6.085^{C}$ & 2005 & $\mathrm{I}(1)$ \\
\hline FD & & -4.033 & 2007 & $-6.111^{\mathrm{B}}$ & 2004 & $\mathrm{I}(1)$ \\
\hline URB & & -4.980 & 1985 & $-6.284^{\mathrm{B}}$ & 1990 & $\mathrm{I}(1)$ \\
\hline
\end{tabular}

Note: ${ }^{\mathrm{B}}$ and ${ }^{\mathrm{C}}$ stand for $1 \%$ and $5 \%$ significance level, respectively. $\mathrm{K}$ and $\mathrm{T}$ represent constant and trend, respectively. 
Table 4. Lee and Strazicich (LS) unit-root test.

\begin{tabular}{|c|c|c|c|c|c|c|}
\hline \multirow{2}{*}{ Variables } & & \multicolumn{2}{|c|}{ Level } & \multicolumn{2}{|c|}{ First Difference } & \multirow[b]{2}{*}{ Decision } \\
\hline & & T-Statistic & Break-Years & T-Statistic & Break-Date & \\
\hline $\mathrm{CO}_{2}$ & \multirow{6}{*}{$\mathrm{K}$ and $\mathrm{T}$} & $-6.263^{C}$ & $\begin{array}{c}1987 \text { and } \\
2008\end{array}$ & $-6.837^{C}$ & $\begin{array}{c}1987 \text { and } \\
2003\end{array}$ & $\mathrm{I}(0) \mathrm{I}(1)$ \\
\hline EN & & $-6.444^{\mathrm{C}}$ & $\begin{array}{c}1985 \text { and } \\
2003\end{array}$ & $-6.599^{C}$ & $\begin{array}{c}1981 \text { and } \\
1994\end{array}$ & $\mathrm{I}(0) \mathrm{I}(1)$ \\
\hline GDP & & $-7.189^{\mathrm{B}}$ & $\begin{array}{l}1989 \text { and } \\
2004\end{array}$ & $-7.070^{\mathrm{B}}$ & $\begin{array}{c}1984 \text { and } \\
2008\end{array}$ & $\mathrm{I}(0) \mathrm{I}(1)$ \\
\hline GCF & & -5.342 & $\begin{array}{c}1989 \text { and } \\
2005\end{array}$ & $-6.058^{\mathrm{D}}$ & $\begin{array}{c}1990 \text { and } \\
2002\end{array}$ & $\mathrm{I}(1)$ \\
\hline FD & & $-6.397^{\mathrm{C}}$ & $\begin{array}{l}1982 \text { and } \\
2005\end{array}$ & -5.684 & $\begin{array}{c}1981 \text { and } \\
2003\end{array}$ & $\mathrm{I}(0)$ \\
\hline URB & & $-6.488^{C}$ & $\begin{array}{c}1982 \text { and } \\
1996\end{array}$ & $-6.633^{\mathrm{D}}$ & $\begin{array}{c}1995 \text { and } \\
2005\end{array}$ & $\mathrm{I}(0) \mathrm{I}(1)$ \\
\hline
\end{tabular}

Note: ${ }^{\mathrm{B}}, \mathrm{C}$, and ${ }^{\mathrm{D}}$ stand for significance level of $1 \%, 5 \%$, and $10 \%$, respectively. $\mathrm{K}$ and $\mathrm{T}$ represent constant and trend, respectively.

We then utilized the ARDL bounds test technique to explore the long-run interconnection among energy consumption, GDP growth, urbanization, financial development, and gross capital formation, in the case of Turkey, by using yearly data stretching between 1960 and 2017. The first phase in evaluating the ARDL bounds test was the selection of the optimal lag order for the indicators in the framework. As a result, the Schwartz Bayesian Criterion (SBC) was utilized. Table 5 illustrates the cointegration outcomes for the two models. The outcome revealed evidence of cointegration in the two models, since the F-statistics (5.48) and (5.25) are greater than the lower- and upper-bound critical values.

Table 5. ARDL bounds test.

\begin{tabular}{|c|c|c|c|c|}
\hline Estimable Model & \multicolumn{2}{|c|}{ First Model of $\mathrm{CO}_{2}$} & \multicolumn{2}{|c|}{ Second Model } \\
\hline Model Specification & \multicolumn{2}{|c|}{$\mathrm{CO}_{2}=\mathrm{f}(\mathrm{Y}, \mathrm{EN}, \mathrm{FD}, \mathrm{GCF}, \mathrm{URB})$} & \multicolumn{2}{|c|}{$\mathrm{CO}_{2}=\mathrm{f}(\mathrm{FD}(\mathrm{Y}), \mathrm{FD}(\mathrm{EN}), \mathrm{FD}(\mathrm{GCF}), \mathrm{FD}(\mathrm{URB}))$} \\
\hline F-statistic & \multicolumn{2}{|c|}{$5.48^{\mathrm{B}}$} & \multicolumn{2}{|c|}{$5.25^{\mathrm{B}}$} \\
\hline \multirow[t]{2}{*}{ Cointegration } & \multicolumn{2}{|c|}{ Yes } & \multicolumn{2}{|c|}{ Yes } \\
\hline & Lower-Bound & Upper-Bound & Lower-Bound & Upper-Bound \\
\hline \multirow{3}{*}{ Significance Level } & $1 \%$ & 4.68 & 3.74 & 5.06 \\
\hline & $5 \%$ & 3.79 & 2.86 & 4.01 \\
\hline & $10 \%$ & 3.35 & 2.45 & 3.52 \\
\hline
\end{tabular}

Note: ${ }^{\mathrm{B}}$ stands for $1 \%$ significance level.

In order to verify the outcomes of the ARDL bounds test, the current study utilized Bayer-Hanck combined cointegration test as a robustness check. Table 6 illustrates the result of the Bayer-Hanck [91] combined the cointegration test. The findings reveal that, at a $5 \%$ level of significance, there is evidence of long-run cointegration amongst the variables used in the two models. 
Table 6. Bayer-Hanck cointegration test.

\begin{tabular}{cccc}
\hline Models & Fisher Statistics & Fisher Statistics & Cointegration Decision \\
\hline $\begin{array}{c}\mathrm{CO}_{2}=\mathrm{f}(\mathrm{Y}, \mathrm{EN}, \mathrm{FD}, \mathrm{GCF}, \\
\mathrm{URB})\end{array}$ & $110.524^{*}$ & $221.048^{*}$ & Yes \\
\hline $\begin{array}{c}\mathrm{CO}_{2}=\mathrm{f}(\mathrm{FD}(\mathrm{Y}), \mathrm{FD}(\mathrm{EN}), \\
\mathrm{FD}(\mathrm{GCF}), \mathrm{FD}(\mathrm{URB}))\end{array}$ & $108.723^{*}$ & $231.048^{*}$ & Yes \\
\hline \multicolumn{2}{c}{$\mathrm{CV}$} & $\mathrm{CV}$ & \\
\hline Significance level at $5 \%$ & 10.576 & 20.143 & \\
\hline
\end{tabular}

Note: $1 \%$ significance level is illustrated by ${ }^{*}$. CV stands for the critical value.

The study also employs the fully modified OLS (FMOLS), dynamic OLS (DOLS) and Canonical Cointegration Regression (CCR) to capture the impact of financial development, urbanization, economic growth, energy consumption and gross capital formation on environmental degradation in Turkey between 1960 and 2016. Furthermore, the present study explored the moderating role of financial development on the long-run impact of financial development, urbanization, economic growth, energy consumption, and gross capital formation on Turkey's environmental degradation.

The empirical results of the FMOLS, DOLS, and CCR (without financial development as moderator) are depicted in Table 6 . In the first model, the findings from the three longrun estimators revealed (i) a positive connection between $\mathrm{CO}_{2}$ emissions and economic growth and (ii) a positive connection between financial development and $\mathrm{CO}_{2}$ emissions. This implies that, keeping other indicators constant, a 1\% increase in FD will deteriorate the quality of the environment by $0.0603 \%, 0.0549 \%$, and $0.2749 \%$, as revealed by the FMOLS, DOLS and CCR, respectively. (iii) Urbanization exerts a positive impact on $\mathrm{CO}_{2}$ emissions. This implies that a $1 \%$ increase in URB will increase $\mathrm{CO}_{2}$ emissions by $1.1479 \%$, $1.0999 \%$, and $0.8789 \%$, as illustrated by FMOLS, DOLS, and CCR, respectively, keeping other indicators constant. (iv) A positive connection between gross capital formation and $\mathrm{CO}_{2}$ emissions. This implies that, keeping other indicators constant, a $1 \%$ increase in GCF will harm environmental quality by $0.3968 \%, 0.4051 \%$, and $1.4607 \%$, as revealed by the FMOLS, DOLS and CCR, respectively. (v) Energy consumption exerts a positive impact on $\mathrm{CO}_{2}$ emissions. This implies that a $1 \%$ increase in $\mathrm{EN}$ will increase $\mathrm{CO}_{2}$ emissions by $0.9307 \%, 0.9196 \%$, and $1.9037 \%$, as illustrated by FMOLS, DOLS, and CCR, respectively, keeping other indicators constant. This study's findings confirm the significance of all the variables employed as determinants of carbon emission in Turkey between 1960 and 2016. This indicates that the vulnerability of energy consumption, gross fixed capital formation, urbanization, economic growth, and financial development are significant for predicting Turkey's environmental degradation.

Finally, we tested the moderating effect of financial development, and the results presented in Table 7 show the result of the long-run estimations with moderating effect (Financial Development). The empirical findings revealed the following: (i) financial development positively moderates the relationship between economic growth and $\mathrm{CO}_{2}$ emissions; (ii) there is no evidence of the moderating effect of financial development on the relationship between economic growth and $\mathrm{CO}_{2}$ emissions; (iii) financial development negatively moderates the relationship between gross capital formation and $\mathrm{CO}_{2}$ emissions; and (iv) financial development negatively moderates the relationship between urbanization and $\mathrm{CO}_{2}$ emissions. It is worth noting these findings when comparing the coefficients of the variables without financial development as a moderator (Table 7). Furthermore, when it is added as moderator (Table 8), GDP, GCF, and URB still maintain their level of significance, but there is a change of sign in the coefficient of GCF and URB, which is an indication that financial development plays a vital role the impact of URB and GCF on $\mathrm{CO}_{2}$. Thus, the moderating effect of financial development aid URB and GCF in mitigating environmental 
degradation. Therefore, it should be considered when initiating plans associated with environmental degradation.

Table 7. Long-run estimations without moderating effect.

\begin{tabular}{|c|c|c|c|c|c|c|}
\hline \multirow[b]{2}{*}{ Regressors } & \multicolumn{2}{|c|}{ FMOLS } & \multicolumn{2}{|c|}{ DOLS } & \multicolumn{2}{|c|}{ CCR } \\
\hline & Co-Efficient & T. Statistic & Coefficient & T. Statistic & Coefficient & T. Statistic \\
\hline $\mathrm{Y}$ & 0.3378 & $3.5225^{\mathrm{B}}$ & 0.3352 & $2.6472^{B}$ & 0.8310 & $2.3037^{C}$ \\
\hline $\mathrm{EN}$ & 0.9307 & $9.7149^{\mathrm{B}}$ & 0.9196 & $7.2816^{\mathrm{B}}$ & 1.9037 & $2.5197^{C}$ \\
\hline GCF & 0.3968 & $3.4711^{\text {В }}$ & 0.4051 & $2.7024^{C}$ & 1.4607 & $2.2831^{C}$ \\
\hline FD & 0.0603 & $2.3170^{C}$ & 0.0549 & $1.6927^{\mathrm{D}}$ & 0.2749 & $2.3469^{C}$ \\
\hline URB & 1.1479 & $3.2113^{\mathrm{B}}$ & 1.0999 & $2.3536^{\mathrm{C}}$ & 0.8789 & 2.1599 C \\
\hline $\mathrm{R}^{2}$ & \multicolumn{2}{|c|}{0.99} & \multicolumn{2}{|c|}{0.99} & \multicolumn{2}{|c|}{0.98} \\
\hline Adj. $R^{2}$ & \multicolumn{2}{|c|}{0.99} & \multicolumn{2}{|c|}{0.99} & \multicolumn{2}{|c|}{0.97} \\
\hline
\end{tabular}

Note: ${ }^{B}, C$, and ${ }^{D}$ stand for significance level of $1 \%, 5 \%$, and $10 \%$, correspondingly. FMOLS, fully modified ordinary least square; DOLS, dynamic ordinary least square; CCR, Canonical Cointegrating Regression.

Table 8. Long-run estimations with moderating effect (financial development).

\begin{tabular}{ccccccc}
\hline & \multicolumn{2}{c}{ FMOLS } & \multicolumn{2}{c}{ DOLS } & \multicolumn{2}{c}{ CCR } \\
\hline Regressors & Coefficient & T. Statistic & Coefficient & T. Statistic & Coefficient & T. Statistic \\
\hline FD(Y) & 0.2821 & $2.0196^{\mathrm{D}}$ & 0.2263 & $2.0701^{\mathrm{D}}$ & 0.7522 & $1.9527^{\mathrm{D}}$ \\
FD(EN) & 0.0157 & 0.8627 & 0.0109 & 0.3911 & 0.0870 & 0.9927 \\
FD(GCF) & -0.8236 & $-8.2661^{\mathrm{B}}$ & -0.7641 & $-5.0541^{\mathrm{B}}$ & -1.7744 & $-3.6690^{\mathrm{B}}$ \\
FD(URB) & -0.1859 & $-3.9839^{\mathrm{B}}$ & -0.2065 & $-3.0852^{\mathrm{B}}$ & -0.3702 & $-1.9100^{\mathrm{D}}$ \\
$\mathrm{R}^{2}$ & \multicolumn{2}{c}{0.99} & 0.99 & 0.95 \\
Adj. $\mathrm{R}^{2}$ & 0.99 & 0.99 & 0.93 \\
\hline Note: ${ }^{\mathrm{B}}, \mathrm{C}^{\mathrm{C}}$, and ${ }^{\mathrm{D}}$ stand for significance level of 1\%, 5\%, and 10\%, correspondingly.
\end{tabular}

In the two models, the $\mathrm{R}^{2}$ values are 0.99 and 0.99 for FMOLS, DOLS, and CCR, showing that $99 \%$ of the discrepancy in $\mathrm{CO}_{2}$ emissions can be explained by energy consumption, urbanization, economic growth, gross capital formation, and economic growth.

\section{Discussion and Conclusions}

\subsection{Discussion}

This study investigates the determinants of carbon emissions in Turkey on the one hand, and on the other hand, investigates the sustainability of the moderating role of Financial Development by using Bayer-Hanck cointegration test, fully modified OLS, dynamic OLS, and Canonical Cointegration Regression estimators for the period from 1960 to 2016. The study confirms the significance of economic growth, energy consumption, urbanization, capital formation, and financial development as determinants of environmental degradation in Turkey. Our finding is consistent with some previous studies that found the significance of economic growth as a determinant of economic growth $[43,44,46]$. In addition, the significance of economic growth as an environmental degradation determinant for Turkey in this study contradicts the study of Ozturk and Acaravci [55], who failed to establish its significance for the period from 1968 to 2005 in Turkey. However, the finding for Turkey is consistent with some previous studies that demonstrated economic growth as a determinant of carbon emissions for Turkey in their studies $[7,38,54,56]$.

The estimators employed in this study confirm that energy consumption, capital formation, financial development, and urbanization are determinants of carbon emission in Turkey over the given year under consideration. In reference to previous studies $[47,48,50]$, energy consumption triggers carbon emissions, which is considered to be a major contributor to climate change. In addition, the significance of financial development as a determinant of carbon emissions is consistent with Alom et al. [87], Charfeddine and Khediri [86], Kong and Wei [88], Nasreem et al. [90], Shahbaz et al. [39], and Xu et al. [84]. Similarly, the capital influence of $\mathrm{CO}_{2}$ emissions is consistent with Solari and Shahbaz [63], 
Hossain et al. [65], and the significant impact of urbanization on $\mathrm{CO}_{2}$ emissions is consistent with Ali et al. [71], Behera and Dash [69], Kirikkaleli and Kalmaz [12], Shahbaz et al. [82], Wang et al. [83], $\mathrm{Xu}$ and Wang [84], and $\mathrm{Zi}$ et al. [70].

Meanwhile, the core question of the study is addressed by our finding that financial development plays a significant role in environmental degradation in Turkey because the sustainability of the moderating role of financial development is statistically in the relationship between economic growth and carbon emissions, capital formation and carbon emissions, and urbanization and carbon emissions. The finding is consistent with Cetin et al. [21], Kalmaz and Kirikkaleli [7], Kirikkaleli and Kalmaz [7], and Ozturk and Acaravci [56], because it indicates that economic growth, capital formation, and urbanization are significant determinants of carbon emission in Turkey. In addition, Aye and Edoja [32] and Yuxiang and Chen [33] suggest that the role of financial development in the reduction of environment cannot be neglected, because there exists an efficient allocation of financial resources to the domestic firms so that they can acquire eco-friendly technology that will generate less carbon emission [2,34]. Moreover, the availability of credit facilities and investment channels by financial systems and international trade would enable an environment for research and development of low-carbon energy sources [12,35-37], implying the need for the policymakers in Turkey to incorporate financial development into the country's eco-friendly policies and regulation.

\subsection{Conclusions}

This study explored the long-run cointegration and causal impact of economic growth, capital formation, energy consumption, urbanization, and financial development on $\mathrm{CO}_{2}$ emissions in Turkey by considering the sustainability of the moderating role of financial development. Hence, we provided new evidence in our study. To the best of our knowledge, no previous studies have investigated the cointegration and causal impact of economic growth, capital formation, energy consumption, urbanization, and financial development with the sustainability of the moderating effect of financial development in Turkey. This study used novel econometrics techniques, including Bayer-Hanck cointegration, FMOLS, DOLS, and CCR, and it used the time-series data between 1960 and 2016, to investigate the cointegration and causal impact of economic growth, capital formation, energy consumption, urbanization, and financial development with the sustainability of the moderating effect of financial development in Turkey empirically.

The novelty of this study is that the significance of the sustainability of the moderating effect of financial development in explaining carbon emissions in Turkey is put forth. It is also interesting to know that financial development is also a significant determinant of carbon emissions in Turkey. At the same time, it also interacts with other variables to explain the environmental degradation in Turkey, making it important to ensure its sustainability for the achievement of sustainable development in Turkey. This should be given adequate consideration by the policymakers to adopt policies that will improve the financial system in Turkey in such a way that it will not contribute to increasing environmental degradation but reducing it. Owing to the significance of financial development as a moderator in the determinants of environmental degradation in Turkey, it has some implications for the Turkish economy. Firstly, the government should assist the financial market through the formulation of a stable policy framework that would encourage the development of less-carbon-intensive technologies; this in no doubt will contribute significantly to the achievement of sustainable development in the country. In addition, financial openness and liberalization could be stimulated by the government so that the business may be motivated to use eco-friendly and novel technologies. Secondly, the businesses in Turkey should be encouraged to use the financial sector's resources to import only efficient eco-friendly technologies and concentrate on technological innovations and investment in research and development. Finally, in addition to the financial policies, there is a need for some reforms that are related to economic and energy policies that would address 
the rising trend of carbon emissions in Turkey and contribute significantly to sustainable development in Turkey.

Though this study contributes significantly to the environmental and financial development literature, especially in Turkey and similar developing countries, the study is not devoid of limitation. This limitation lies in the length of the period covered due to the data availability and the use of only Turkey. Thus, future studies can explore a greater time span and possibly use panel data. This will provide more understanding for a wider coverage, owing to the fact that the issue of environmental sustainability goes beyond borders.

Author Contributions: Conceptualization, H.R. and J.A.O.; methodology, T.S.A. and J.A.O.; J.A.O. and T.S.A.; formal analysis, J.A.O. and T.S.A.; investigation, H.R.; resources, J.A.O. and T.S.A.; data curation, J.A.O.; writing-original draft preparation, H.R., J.A.O. and T.S.A.; writing-review and editing, W.-K.W.; supervision, H.R. and W.-K.W.; project administration, H.R.; funding acquisition, W.-K.W. All authors have read and agreed to the published version of the manuscript.

Funding: The APC was funded by W.-K.W.

Institutional Review Board Statement: The study was conducted according to the research guidelines approved by the Ethics Committees of Authors Institutions.

Informed Consent Statement: Not applicable.

Data Availability Statement: Not applicable.

Acknowledgments: The authors would like to thank the Editor, Editor Assistant for their guidance and follow-up. Also, the authors would like to thank the anonymous referee for their valuable comments to enhance our paper to appear in its current format. The fourth author would like to thank Robert B. Miller and Howard Thompson for their continuous guidance and encouragement. This research has been supported by Cyprus International University, Asia University, China Medical University, The Hang Seng University of Hong Kong, Research Grants Council (RGC) of Hong Kong (project number 12500915), and Ministry of Science and Technology (MOST, Project Numbers 106-2410-H-468-002 and 107-2410-H-468-002-MY3), Taiwan.

Conflicts of Interest: The authors declare no conflict of interest.

\section{References}

1. Intergovernmental Panel on Climate Change (IPCC). Climate Change 2013: The Physical Science Basis. Contribution of Working Group I to the Fifth Assessment Report of the IPCC; Stocker, T.F., Qin, D., Plattner, G.-K., Tignor, M., Allen, S.K., Boschung, J., Nauels, A., Xia, Y., Bex, V., Midgley, P.M., Eds.; IPCC: Geneva, Switzerland, 2013.

2. Chapman, A.; Fujii, H.; Managi, S. Key drivers for cooperation toward sustainable development and the management of $\mathrm{CO}_{2}$ emissions: Comparative analysis of six Northeast Asian countries. Sustainability 2018, 10, 244. [CrossRef]

3. Gökmenoğlu, K.; Taspinar, N. The relationship between $\mathrm{CO}_{2}$ emissions, energy consumption, economic growth and FDI: The case of Turkey. J. Int. Trade Econ. Dev. 2016, 25, 706-723.

4. International Energy Agency Statistics (IEA Statistics). CO2 Emissions from Fuel Combustion Highlights. 2014. Available online: https:/ / www.iea.org/publications / freepublications / publication/CO2EmissionsFromFuelCombustionHighlights2014. pdf (accessed on 6 September 2020).

5. World Bank. World Development Indicators. 2020. Available online: http://data.worldbank.org/ (accessed on 5 September 2020).

6. Bilgen, S.; Keleş, S.; Kaygusuz, A.; Sarı, A.; Kaygusuz, K. Global warming and renewable energy sources for sustainable development: A case study in Turkey. Renew. Sustain. Energy Rev. 2008, 12, 372-396. [CrossRef]

7. Kirikkaleli, D.; Kalmaz, D.B. Testing the moderating role of urbanization on the environmental Kuznets curve: Evidence from an emerging market. Environ. Sci. Pollut. Res. 2020, 27, 38169-38180. [CrossRef]

8. TUIK Main Statistics. Available online: http:/ / www.turkstat.gov.tr (accessed on 5 September 2020).

9. Akca, Y.; Ozturk, M.; Gunes, A.N. Evaluation of Environment Policies in Turkey's Development Plans. J. Mgmt. Sustain. 2018, 8, 28. [CrossRef]

10. Thakur, B.K.; Rout, H.S.; Chakraborty, T. Environmental Degradation, Sustainable Development and Human Well-being: Evidence from India. Manthan J. Commer. Manag. 2014, 1, 101-120. [CrossRef]

11. Cioca, L.I.; Ivascu, L.; Rada, E.C.; Torretta, V.; Ionescu, G. Sustainable development and technological impact on $\mathrm{CO}_{2}$ reducing conditions in Romania. Sustainability 2015, 7, 1637-1650. [CrossRef]

12. Wang, C.; Wang, F.; Zhang, H.; Ye, Y.; Wu, Q.; Su, Y. Carbon emissions decomposition and environmental mitigation policy recommendations for sustainable development in Shandong province. Sustainability 2014, 6, 8164-8179. [CrossRef] 
13. Zhao, X.; Zhang, Y.; Liang, J.; Li, Y.; Jia, R.; Wang, L. The sustainable development of the economic-energy-environment (3E) system under the carbon trading (CT) mechanism: A hinese case. Sustainability 2018, 10, 98. [CrossRef]

14. Dinda, S.; Coondoo, D. Income and emission: A panel data-based cointegration analysis. Ecol. Econ. 2006, 57, 167-181. [CrossRef]

15. Grossman, G.M.; Krueger, A.B. Economic growth and the environment. Q. J. Econ. 1995, 110, 353-377. [CrossRef]

16. Lee, C.C.; Lee, J.D. Income and $\mathrm{CO}_{2}$ emissions: Evidence from panel unit root and cointegration tests. Energy Policy 2009, 37, 413-423. [CrossRef]

17. Lorente, D.B.; Álvarez-Herranz, A. Economic growth and energy regulation in the environmental Kuznets curve. Environ. Sci. Pollut. Res. 2016, 23, 16478-16494. [CrossRef]

18. Kraft, J.; Kraft, A. On the relationship between energy and GNP. J. Energy Dev. 1978, 3, 401-403.

19. Yuan, J.; Zhao, C.; Yu, S.; Hu, Z. Electricity consumption and economic growth in China: Cointegration and co-feature analysis. Energy Econ. 2007, 29, 1179-1191. [CrossRef]

20. Anatasia, V. The Causal Relationship between GDP, Exports, Energy Consumption, and $\mathrm{CO}_{2}$ in Thailand and Malaysia. Int. J. Econ. Perspect. 2015, 9, 37-48.

21. Cetin, M.; Ecevit, E.; Yucel, A.G. Structural breaks, urbanization and $\mathrm{CO}_{2}$ emissions: Evidence from Turkey. J. Appl. Econ. Bus. Res. 2018, 8, 122-139.

22. Heidari, H.; Katircioğlu, S.T.; Saeidpour, L. Economic growth, $\mathrm{CO}_{2}$ emissions, and energy consumption in the five ASEAN countries. Int. J. Electr. Power Energy Syst. 2015, 64, 785-791. [CrossRef]

23. Koçak, E. Türkiye de Çevresel Kuznets Eğrisi Hipotezinin Geçerliliği: ARDL Sınır Testi Yaklaşımı. İşletme İktisat Çalışmaları Dergisi 2014, 2, 62-73.

24. Katircioglu, S. Investigating the role of oil prices in the conventional EKC model: Evidence from Turkey. Asian Econ. Financ. Rev. 2017, 7, 498-508. [CrossRef]

25. Katircioglu, S.; Katircioğlu, S.; Altinay, M. Interactions between energy consumption and imports: Empirical evidence from Turkey. J. Comp. Asian Dev. 2017, 16, 161-178. [CrossRef]

26. Yavuz, N.Ç. $\mathrm{CO}_{2}$ emission, energy consumption, and economic growth for Turkey: Evidence from a cointegration test with a structural break. Energy Sources Part. B 2014, 9, 229-235. [CrossRef]

27. Ahmad, N.; Du, L.; Lu, J.; Wang, J.; Li, H.Z.; Hashmi, M.Z. Modelling the $\mathrm{CO}_{2}$ emissions and economic growth in Croatia: Is there any environmental Kuznets curve? Energy 2017, 123, 164-172. [CrossRef]

28. Saint Akadiri, S.; Lasisi, T.T.; Uzuner, G.; Akadiri, A.C. Examining the impact of globalization in the environmental Kuznets curve hypothesis: The case of tourist destination states. Environ. Sci. Pollut. Res. 2019, 26, 12605-12615. [CrossRef]

29. Alam, M.M.; Murad, M.W.; Noman, A.H.M.; Ozturk, I. Relationships among carbon emissions, economic growth, energy consumption and population growth: Testing Environmental Kuznets Curve hypothesis for Brazil, China, India and Indonesia. Ecol. Indic. 2016, 70, 466-479. [CrossRef]

30. Dogan, E.; Taspinar, N.; Gokmenoglu, K.K. Determinants of ecological footprint in MINT countries. Energy Environ. 2019, 30, 1065-1086. [CrossRef]

31. Dogan, E.; Inglesi-Lotz, R. The impact of economic structure to the environmental Kuznets curve (EKC) hypothesis: Evidence from European countries. Environ. Sci. Pollut. Res. 2020, 27, 1-8. [CrossRef]

32. Aye, G.C.; Edoja, P.E. Effect of economic growth on $\mathrm{CO}_{2}$ emission in developing countries: Evidence from a dynamic panel threshold model. Cogent Econ. Financ. 2017, 5, 1-22. [CrossRef]

33. Yuxiang, K.; Chen, Z. Financial development and environmental performance: Evidence from China. Environ. Dev. Econ. 2010, 16, 1-19. [CrossRef]

34. Frankel, J.; Rose, A. An estimate of the effect of common currencies on trade and income. Q. J. Econ. 2002, 117, 437-466. [CrossRef]

35. Ehigiamusoe, K.U.; Lean, H.H. Effects of energy consumption, economic growth, and financial development on carbon emissions: Evidence from heterogeneous income groups. Environ. Sci. Pollut. Res. Int. 2019, 26, 22611-22624. [CrossRef]

36. Nasir, M.A.; Huynh, T.L.D.; Tram, H.T.X. Role of financial development, economic growth \& foreign direct investment in driving climate change: A case of emerging ASEAN. J. Environ. Manag. 2019, 242, 131-141.

37. Xu, Z.; Baloch, M.A.; Meng, F.; Zhang, J.; Mahmood, Z. Nexus between financial development and $\mathrm{CO}_{2}$ emissions in Saudi Arabia: Analyzing the role of globalization. Environ. Sci. Pollut. Res. 2018, 25, 28378-28390. [CrossRef] [PubMed]

38. Charfeddine, L.; Kahia, M. Impact of renewable energy consumption and financial development on $\mathrm{CO}_{2}$ emissions and economic growth in the MENA region: A panel vector autoregressive (PVAR) analysis. Renew. Energy 2019, 139, 198-213. [CrossRef]

39. Shahbaz, M.; Ozturk, I.; Afza, T.; Ali, A. Revisiting the Environmental Kuznets Curve in a Global Economy. Renew. Sustain. Energy Rev. 2013, 25, 494-502. [CrossRef]

40. Moghadam, H.E.; Dehbashi, V. The impact of financial development and trade on environmental quality in Iran. Empir. Econ. 2018, 54, 1777-1799. [CrossRef]

41. Hossain, M.S. Panel estimation for $\mathrm{CO}_{2}$ emissions, energy consumption, economic growth, trade openness and urbanization of newly industrialized countries. Energy Policy 2011, 39, 6991-6999. [CrossRef]

42. Pata, U.K. Renewable energy consumption, urbanization, financial development, income and CO2 emissions in Turkey: Testing EKC hypothesis with structural breaks. J. Clean. Prod. 2018, 187, 770-779. [CrossRef]

43. Shahbaz, M.; Shahzad, S.J.H.; Ahmad, N.; Alam, S. Financial development and environmental quality: The way forward. Energy Policy 2016, 98, 353-364. [CrossRef] 
44. Akbostanc1, E.; Türüt-Aşık, S.; Tunç, G.İ. The relationship between income and environment in Turkey: Is there an environmental Kuznets curve? Energy Policy 2009, 37, 861-867. [CrossRef]

45. Dogan, E.; Turkekul, B. $\mathrm{CO}_{2}$ emissions, real output, energy consumption, trade, urbanization and financial development: Testing the EKC hypothesis for the USA. Environ. Sci. Pollut. Res. 2016, 23, 1203-1213. [CrossRef] [PubMed]

46. Lean, H.H.; Smyth, R. $\mathrm{CO}_{2}$ emissions, electricity consumption and output in ASEAN. Appl. Energy 2010, 87, 1858-1864. [CrossRef]

47. Apergis, N.; Payne, J.E. $\mathrm{CO}_{2}$ emissions, energy usage, and output in Central America. Energy Policy 2009, 37, 3282-3286. [CrossRef]

48. Ayeche, M.B.; Barhoumi, M.; Hammas, M.A. Causal linkage between economic growth, financial development, trade openness and $\mathrm{CO}_{2}$ emissions in European Countries. Am. J. Environ. Eng. 2016, 6, 110-122.

49. Kapusuzoglu, A. Causality relationships between carbon dioxide emissions and economic growth: Results from a multi-country study. Int. J. Econ. Perspect. 2014, 8, 5-15.

50. Katırcıoğlu, S.; Fethi, S.; Kalmaz, D.B.; Çağlar, D. Interactions between energy consumption, international trade, and real income in Canada: An empirical investigation from a new version of the Solow growth model. Int. J. Green Energy 2016, 13, 1059-1074. [CrossRef]

51. Narayan, P.K.; Smyth, R. Energy consumption and real GDP in G7 countries: New evidence from panel cointegration with structural breaks. Energy Econ. 2008, 30, 2331-2341. [CrossRef]

52. Yuan, J.H.; Kang, J.G.; Zhao, C.H.; Hu, Z.G. Energy consumption and economic growth: Evidence from China at both aggregated and disaggregated levels. Energy Econ. 2008, 30, 3077-3094. [CrossRef]

53. Sarkodie, S.A.; Strezov, V. Effect of foreign direct investments, economic development and energy consumption on greenhouse gas emissions in developing countries. Sci. Total Environ. 2019, 646, 862-871. [CrossRef]

54. Halicioglu, F. An econometric study of $\mathrm{CO}_{2}$ Emissions, Energy Consumption, Income and Foreign Trade in Turkey. Energy Policy 2009, 37, 1156-1164. [CrossRef]

55. Ozturk, I.; Acaravci, A. $\mathrm{CO}_{2}$ Emissions, Energy Consumption and Economic Growth in Turkey. Renew. Sustain. Energy Rev. 2010, 14, 3220-3225. [CrossRef]

56. Ozturk, I.; Acaravci, A. The Long-Run and Causal Analysis of Energy, Growth, Openness and Financial Development on Carbon Emissions in Turkey. Energy Econ. 2013, 36, 262-267. [CrossRef]

57. Bekhet, H.A.; Yasmin, T.; Al-Smadi, R.W. Dynamic linkages among financial development, economic growth, energy consumption, $\mathrm{CO}_{2}$ emissions and gross fixed capital formation patterns in Malaysia. Int. J. Bus. Glob. 2017, 18, 493-523. [CrossRef]

58. Lee, C.C. Energy consumption and GDP in developing countries: A co integrated panel analysis. Energy Econ. 2005, 27, 415-427. [CrossRef]

59. Soytas, U.; Sari, R. Energy consumption, economic growth, and carbon emissions: Challenges faced by an EU candidate member. Ecol. Econ. 2009, 68, 1667-1675. [CrossRef]

60. Apergis, N.; Payne, J.E. Renewable energy consumption and growth in Eurasia. Energy Econ. 2010, 32, 1392-1397. [CrossRef]

61. Apergis, N.; Payne, J.E. Renewable and non-renewable energy consumption-growth. Energy Econ. 2012, 34, 733-738. [CrossRef]

62. Liddle, B. The importance of energy quality in energy intensive manufacturing: Evidence from panel cointegration and panel FMOLS. Energy Econ. 2012, 34, 1810-1825. [CrossRef]

63. Solarin, S.A.; Shahbaz, M. Natural gas consumption and economic growth: The role of foreign direct investment, capital formation and trade openness in Malaysia. Renew. Sustain. Energy Rev. 2015, 42, 835-845. [CrossRef]

64. Ajao, M.G. Stock market development, capital formation and growth in Nigeria. Int. J. Curr. Res. 2011, 33, 382-388.

65. Hossain, M.K.; Hossain, A.; Sadi, R. An examination of the relationship between stock market and economic growth: A study in Malaysia. J. Transform. Entrep. 2013, 1, 124-133. [CrossRef]

66. Ugochukwu, U.S.; Chinyere, U.P. The impact of capital formation on the growth of Nigerian economy. Res. J. Financ. Account. 2013, 4, 36-42.

67. Ray, S. An empirical investigation into causal relationship between gross fixed capital formation and stock price in India. Am. J. Bus. Econ. Manag. 2013, 1, 1-8.

68. Odugbesan, J.A.; Rjoub, H. Relationship among Economic Growth, Energy Consumption, $\mathrm{CO}_{2}$ Emission, and Urbanization: Evidence from MINT Countries. SAGE Open 2020, 10. [CrossRef]

69. Behera, S.R.; Dash, D.P. The effect of urbanization, energy consumption, and foreign direct investment on the carbon dioxide emissions in the SSEA (South and Southeast Asian) region. Renew. Sustain. Energy Rev. 2017, 70, 96-106. [CrossRef]

70. Zi, C.; Jieb, W.; Hong-Bo, C. $\mathrm{CO}_{2}$ emissions and urbanization correlation in China based on threshold analysis. Ecol. Indic. 2016, 61, 193-201. [CrossRef]

71. Ali, H.S.; Law, S.H.; Zannah, T.I. Dynamic impact of urbanization, economic growth, energy consumption and trade openness on $\mathrm{CO}_{2}$ emissions in Nigeria. Environ. Sci. Pollut. Res. 2016, 23, 12435-12443. [CrossRef] [PubMed]

72. Farhani, S.; Ozturk, I. Causal relationship between $\mathrm{CO}_{2}$ emissions, real GDP, energy consumption, financial development, trade openness and urbanization in Tunisia. Environ. Sci. and Pollut. Res. 2015, 22, 15663-15676. [CrossRef] [PubMed]

73. Sharma, S.S. Determinants of carbon dioxide emissions: Empirical evidence from 69 countries. Appl. Energy 2011, 88, 376-382. [CrossRef]

74. Mol, A.P.J.; Spaargaren, G. Ecological modernization theory in debate: A review. Environ. Politics 2000, 9, 17-49. [CrossRef] 
75. McGranahan, G.; Jacobi, P.; Songsore, J.; Surjadi, C.; Kjellen, M. The Citizen at rRisk: From Urban Sanitation to Sustainable Cities; Earthscan: London, UK, 2001.

76. Burton, E. The compact city: Just or just compact? A preliminary analysis. Urban. Stud. 2000, 37, 1969-2001. [CrossRef]

77. Dodman, D. Blaming cities for climate change? An analysis of urban greenhouse gas emissions inventories. Environ. Urban. 2009, 21, 185-201. [CrossRef]

78. Glaeser, E.L.; Kahn, M.E. The greenness of cities: Carbon dioxide emissions and urban development. J. Urban. Econ. 2010, 67, 404-418. [CrossRef]

79. Grimm, N.B.; Faeth, S.H.; Golubiewski, N.E.; Redman, C.L.; Wu, J.; Bai, X.; Briggs, J.M. Global change and the ecology of cities. Science 2008, 319, 756-760. [CrossRef] [PubMed]

80. Martínez-Zarzoso, I.; Maruotti, A. The impact of urbanization on $\mathrm{CO}_{2}$ emissions: Evidence from developing countries. Ecol. Econ. 2011, 70, 1344-1353. [CrossRef]

81. Saidi, K.; Mbarek, M.B. The impact of income, trade, urbanization, and financial development on $\mathrm{CO}_{2}$ emissions in 19 emerging economies. Environ. Sci. Pollut. Res. 2017, 24, 12748-12757. [CrossRef]

82. Shahbaz, M.; Khraief, N.; Uddin, G.S.; Ozturk, I. Environmental Kuznets curve in an open economy: A bounds testing and causality analysis for Tunisia. Renew. Sustain. Energy Rev. 2014, 34, 325-336. [CrossRef]

83. Wang, Y.; Kang, Y.; Wang, J.; Xu, L. Panel estimation for the impacts of population-related factors on $\mathrm{CO}_{2}$ emissions: A regional analysis in China. Ecol. Indic. 2017, 78, 322-330. [CrossRef]

84. Xu, H.; Zhang, W. The causal relationship between carbon emissions and land urbanization quality: A panel data analysis for Chinese provinces. J. Clean. Prod. 2016, 137, 241-248. [CrossRef]

85. Sy, A.; Tinker, T.; Derbali, A.; Jamel, L. Economic growth, financial development, trade openness and $\mathrm{CO}_{2}$ emissions in European countries. Afr. J. Account. Audit. Financ. 2016, 5, 1226-1235.

86. Charfeddine, L.; Khediri, K.B. Financial development and environmental quality in UAE: Cointegration with structural breaks. Renew. Sustain. Energy Rev. 2016, 55, 1322-1335. [CrossRef]

87. Alom, K.; Uddin, A.N.M.; Islam, N. Energy consumption, $\mathrm{CO}_{2}$ emissions, urbanization and financial development in Bangladesh: Vector error correction model. J. Glob. Econ. Manag. Bus. Res. 2017, 9, 178-189.

88. Kong, Y.; Wei, F. Financial development, financial structure and carbon emission. Environ. Eng. Manag. J. 2017, 16, 1609-1622.

89. Al-Mulali, U.; Tang, C.F.; Ozturk, I. Does financial development reduce environmental degradation? Evidence from a panel study of 129 countries. Environ. Sci. Pollut. Res. 2015, 22, 14891-14900. [CrossRef] [PubMed]

90. Nasreen, S.; Anwar, S.; Ozturk, I. Financial stability, energy consumption and environmental quality: Evidence from South Asian economies. Renew. Sustain. Energy Rev. 2017, 67, 1105-1122. [CrossRef]

91. Bayer, C.; Hanck, C. Combining non-cointegration tests. J. Time Ser. Anal. 2013, 34, 83-95. [CrossRef]

92. Zivot, E.; Andrews, D.W.K. Further Evidence on the Great Crash, the OilPrice Shock and the Unit Root Hypothesis. J. Bus. Econ. Stat. 1992, 10, 251-270.

93. Lee, J.; Strazicich, M.C. Minimum Lagrange multiplier unit root test with two structural breaks. Rev. Econ. Stat. 2003, 85, 1082-1089. [CrossRef]

94. Phillips, P.C.B.; Perron, P. Testing for a Unit Root in Time Series Regression. Biometrika 1988, 75, 335-346. [CrossRef]

95. Vougas, D.V. Reconsidering LM unit root testing. J. Appl. Stat. 2003, 30, 727-741. [CrossRef]

96. Pesaran, M.H.; Shin, Y.; Smith, R.J. Bounds testing approaches to the analysis of level relationships. J. Appl. Econom. 2001, 16, 289-326. [CrossRef]

97. Balsalobre-Lorente, D.; Álvarez-Herranz, A.; Shahbaz, M. The long-term effect of economic growth, energy innovation, energy use on environmental quality. In Energy and Environmental Strategies in the Era of Globalization; Springer: Cham, Swtizerland, 2019; pp. 1-34.

98. Engle, R.F.; Granger, C.W. Co-integration and error correction: Representation, estimation, and testing. Econom. J. Econom. Soc. 1987, 55, 251-276. [CrossRef]

99. Johansen, S. Estimation and hypothesis testing of cointegration vectors in Gaussian vector autoregressive models. J. Econom. Soc. 1991, 59, 1551-1580. [CrossRef]

100. Boswijk, H.P. Testing for an unstable root in conditional and structural error correction models. J. Econom. 1994, 63, 37-60. [CrossRef]

101. Banerjee, A.; Dolado, J.; Mestre, R. Error-correction mechanism tests for cointegration in a single-equation framework. J. Time Ser. Anal. 1998, 19, 267-283. [CrossRef]

102. Bekun, F.V.; Alola, A.A.; Sarkodie, S.A. Toward a sustainable environment: Nexus between CO2 emissions, resource rent, renewable and nonrenewable energy in 16-EU countries. Sci. Total Environ. 2019, 657, 1023-1029. [CrossRef] [PubMed]

103. Phillips, P.C.; Hansen, B.E. Statistical inference in instrumental variables regression with I (1) processes. Rev. Econ. Stud. 1990, 57, 99-125. [CrossRef]

104. Stock, J.H.; Watson, M.W. A simple estimator of cointegrating vectors in higher order integrated systems. Econom. J. Econom. Soc. 1993, 61, 783-820. [CrossRef] 